\title{
POTENSI PEMANFAATAN LIMBAH TANDAN BUAH KOSONG KELAPA SAWIT SEBAGAI BAHAN ALTERNATIF PULP
}

\author{
(Potential Use of Empty Fruit Bunch Waste for Alternative Pulp Material) \\ Lutfy Abdulah, Nina Mindawati, A. Syaffari Kosasih \\ Pusat Litbang Peningkatan Produktivitas Hutan \\ Kampus Balitbang Kehutanan, Jl. Gunung Batu No. 5 Po.Box 331, Bogor 16610 \\ Telp. (0251) 631238, Faks. (0251) 7520005
}

Naskah masuk : 10 Februari 2012; Naskah diterima : 27 Agustus 2012

\begin{abstract}
The growth of oil palm plantation area for Crude Palm Oil (CPO) has been increasing. In Indonesia, oil palm plantation is more than 5 million ha with 14 million of CPO production. However, there are still unutilized wastes like Empty Fruit Bunch (EFB) which can be processed for some other products. EFB can be processed for pulp, craft, plastics and particle board. With Clorin Bleaching Free Technology, EFB can be processed for paper with $75-80 \%$ brightness. Wastes of EFB is related to plantation age. Average of EFB biomass is 10.27 ton ha $\mathrm{C}^{-1}$ and can give income for about USD 28 per ha. The enhancement of economic value can control forested area conversion to palm oil plantation.
\end{abstract}

Keywords: EFBs Biomass, palm oil,pulp, additional income

\begin{abstract}
ABSTRAK
Pertumbuhan perkebunan kelapa sawit untuk produksi minyak semakin meningkat. Lebih dari 5 juta hektar kebun kelapa sawit yang ada di Indonesia dengan produksi minyak sawit mencapai 14 juta ton. Potensi kebun tersebut menyimpan limbah tandan buah kosong (EFB) yang sangat tinggi yang dapat dimanfaatkan sebagai bahan alternatif menghasilkan pulp, kerajinan, plastik dan dengan teknologi Chlorin Bleaching Free pada EFB dapat dihasilkan kertas dengan tingkat keputihan mencapai $75-80 \%$. Limbah EFB memiliki kaitan yang erat dengan umur. Biomassa EFB mencapai 10,27 ton/ha dan bila dimanfaatkan untuk produksi pulp dapat menghasilkan $28 \mathrm{USD} / \mathrm{Ha}$. Peningkatan nilai ekonomi dapat mengendalikan konversi lahan berhutan untuk pembangunan perkebunan kelapa sawit.
\end{abstract}

Kata kunci : Biomassa EFB, kelapa sawit, pulp, tambahan penghasilan

\section{PENDAhULUAN}

\section{A. Latar Belakang}

Kelapa sawit merupakan salah satu tanaman perkebunan yang dapat diolah sebagai bahan makanan, pakan ternak, bioenergi dan kosmetik dan juga sebagai sumber biopolymer seperti polyhydroxyalkonates (PHAs) dan polylactate (PLAs) (Abdullah et al., 2011). Pemanfaatan biomassa kelapa sawit sebagai bioenergi memiliki peluang yang sangat besar, terutama di negara maju sebagai upaya untuk pemanfaatan energi lestari. Negara maju berharap banyak dari biomassa sebagai sumberdaya energi lestari untuk membantu mendapatkan tujuan dalam mitigasi perubahan iklim dengan menggunakan energi ter- barukan, keamanan energi dan pembangunan berkelanjutan (Boons dan Mendoza, 2010). Selain hasil olahan yang telah dieksplorasi tersebut, limbah kelapa sawit dapat dimanfaatkan sebagai bahan pengganti dan pelengkap industri kayu berupa papan dan pulp (Tanaka et al., 2006).

Pengolahan limbah kelapa sawit seperti tandan buah kosong (Empty Fruit Bunch, EFB) sebagai bahan pulp sedang dikembangkan di Malaysia. Malaysia dengan luas perkebunan kelapa sawit mencapai 4,3 juta hektar dengan jumlah pohon antara 135 - 145 pohon/ha (Wan Asma et al., 2010) telah memanfatkan limbah EFB untuk produksi pulp. Kebutuhan pulp Malaysia mencapai 1,8 juta ton/tahun dan dari jumlah tersebut $60 \%$ berasal dari bahan yang diimpor. Pemanfaatan limbah kelapa sawit diproyeksikan akan meme- 
nuhi 1,6 juta ton/tahun dari 4 juta ton/tahun produksi EFB (Tanaka et al., 2006).

Sejalan dengan laju permintaan kertas domestik dan global yang terus meningkat maka pengelolaan limbah EFB yang efisien dan efektif akan dapat memenuhi kebutuhan kertas domestik dan ekspor. Pada tahun 2010 konsumsi kertas domestik mencapai 6,8 juta ton, sementara realisasi sebanyak 11,6 juta ton dari kapasitas terpasang produksi kertas dalam negeri sebesar 12,9 juta ton sekitar. Sisa produksi kertas domestik di ekspor. Sementara produk kertas impor tercatat men-capai 0,3 juta ton (Direktorat Jenderal Industri Agro, 2011).

Selama ini penggunaan bahan baku untuk produksi pulp dan kertas berasal dari HTI (hutan tanaman industri) belum memenuhi kapasitas terpasang produksi kertas nasional. Untuk itu pemanfaatan limbah EFB untuk bahan baku kertas dapat meningkatkan nilai perkebunan kelapa sawit selain minyak dan produk lain yang dihasilkan. Upaya pemanfaatan bagian tanaman kelapa sawit telah gencar dilaksanakan di Malaysia. Hasil produksi dari perkebunan kelapa sawit menyumbang USD 6,14 milyar bagi GNP (Gross National Product) Malaysia yang diekspor ke Cina, India, Belanda dan Pakistan. Nilai penjualan dari hasil diversifikasi produk dari tanaman kelapa sawit merupakan sektor ketiga yang berkontribusi pada GNP Malaysia (Wan Asma et al., 2010).

Penelitian ini bermanfaat untuk menduga limbah EFB yang tidak termanfaatkan selama ini. Tanaka et al. (2004) mengatakan bahwa 40\% dari biomassa EFB dapat diolah menjadi pulp. Bila limbah tersebut dimanfaatkan, penelitian ini menjawab optimalisasi dan nilai tambah ekonomi dari usaha perkebunan kelapa sawit sebagai bahan pertimbangan peningkatan nilai ekonomi hutan jika dibandingkan dengan bentuk penggunaan kawasan hutan untuk pembangunan sektor bukan kehutanan.

\section{B. Tujuan}

Tujuan dari penelitian ini adalah (1) menduga potensi biomasa EFB yang ada dari perkebunan kelapa sawit yang telah dibangun dan peluang pemanfaatannya sebagai alternatif pulp, (2) menduga besarnya tambahan pendapatan yang akan diperoleh bila limbah EFB dimanfaatkan untuk pulp.

\section{BAHAN DAN METODE}

\section{A. Metode Pendugaan Biomassa EFB (Empty Fruit Bunch)}

Pendugaan biomassa kelapa sawit secara langsung tidak ada, namun dalam penelitian ini alometrik pendugaan biomassa oleh Syahrinudin (2005). Pendugaan tersebut tidak mempertimbangkan kerapatan tegakan kelapa sawit, jenis tutupan tanah dan kemiringan lahan, tetapi berupa plot lingkaran seluas 0,05 ha dan jari-jari 12,6 meter dengan minimal terdapat 7 pohon dalam satu plot. Berdasarkan metode tersebut, diperoleh penduga biomassa buah sawit yang dipanen pada kebund engan umur 3,10, 20 dan 30 tahun di Sumatera dan Kalimantan Timur (Tabel 1) dan persamaannya (Gambar 1).

\section{B. Pendugaan Tambahan Pendapatan}

Pendugaan tambahan pendapatan dari hasil pengusahaan pulp dari pemanfaatan limbah tandan buah kosong dengan mendekati total pendapatan dan biaya produksi pulp dengan mempertimbangkan faktor produksi pulp dari jenis kayu-kayuan. Untuk memperoleh informasi nilai tambah menggunakan metode studi pustaka terkait yang menjelaskan tentang pendugaan nilai tambah. Salah satu teknik menduga nilai tambah adalah dengan menggunakan pendekatan harga per satuan produksi, biaya produksi dan rendemen sebagaimana disampaikan oleh Silalahi (2007).

Tabel (Table) 1. Biomassa buah sawit yang dipanen di Sumatera (Biomass Harvested of Oil Palm Fruit in Sumatera)

\begin{tabular}{|c|c|}
\hline $\begin{array}{c}\text { Umur Kebun } \\
\text { (tahun) }\end{array}$ & $\begin{array}{c}\text { Biomassa Buah yang Dipanen } \\
\left(\mathrm{Mg} \mathrm{ha}^{-1}\right)\end{array}$ \\
\hline 3 & 10,06 \\
\hline 10 & 32,82 \\
\hline 20 & 45,92 \\
\hline 30 & 53,58 \\
\hline
\end{tabular}

Sumber (Source): Syahrinudin (2005) 


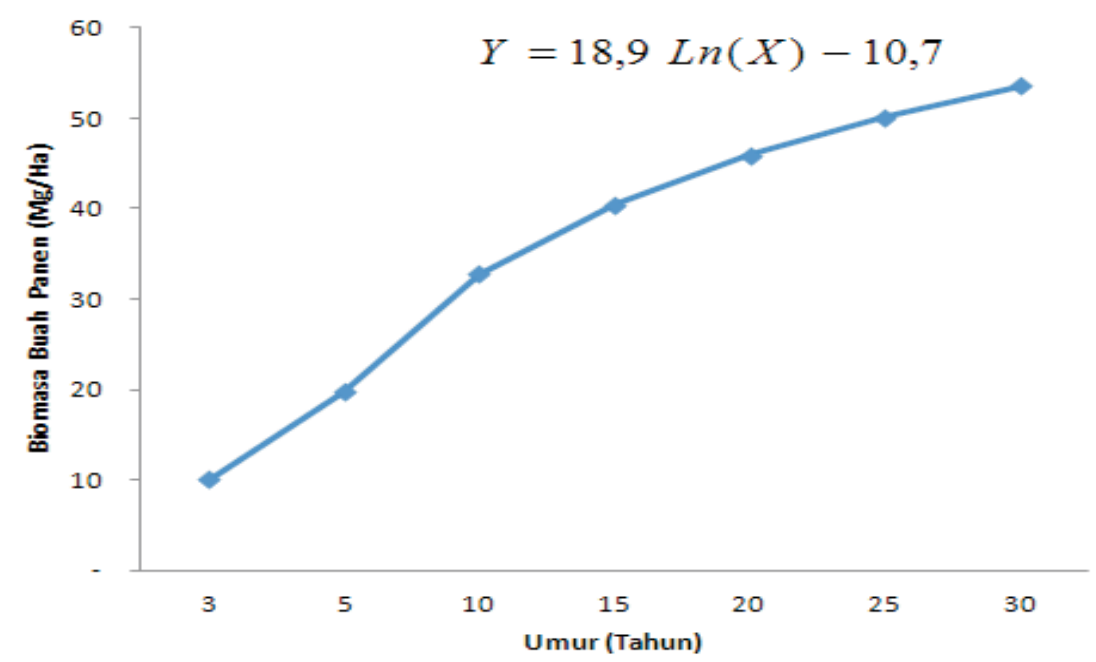

Gambar(Figure) 1. Kurva dari hubungan biomassa bagian pohon kelapa sawit dengan umur kebun di Sumatera (Syahrinudin, 2005) (Curve of relation of biomass parts with age of plantation in Sumatera (Syahrinudin, 2005))

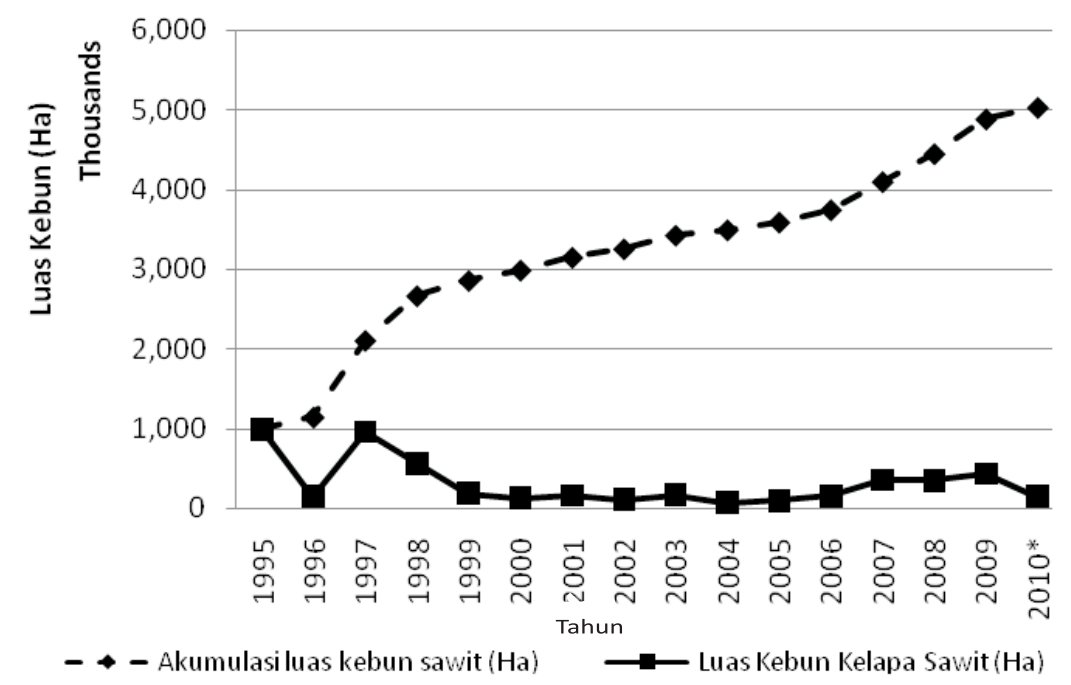

Gambar(Figure) 2. Perkembangan luas perkebunan kelapa sawit (Growth of oil palm plantation area) (BPS, 2010)

\section{Data Pendukung}

Data pendukung yang digunakan dalam penelitian ini adalah luas perkebunan sawit Indonesia sejak tahun 1995 yang diperoleh dari Badan Pusat Statistik tahun 2010 (Gambar 2).

\section{Analisis Data}

1. Pendugaan Biomassa EFB dianalisis dengan menggunakan alometrik (Syahrinudin, 2005): $\mathrm{Y}=18,9 \operatorname{Ln}(\mathrm{X})-10,7$

dimana $\mathrm{Y}=$ Biomassa buah Panen $\left(\mathrm{Mg} . \mathrm{Ha}^{-1}\right)$ $\mathrm{X}=$ UmurTanaman (Tahun)
2. Pendugaan Produksi Pulp dari biomassa EFB, diasumsikan sebesar $40 \%$. Adapun rumus yang digunakan adalah $\mathrm{P}=\mathrm{Y}$ x $40 \%$, dimana $\mathrm{P}$ adalah pulp (ton) dan $\mathrm{Y}$ adalah biomassa (ton/ha)

Pendugaan Tambahan Pendapatan Dari Pemanfaatan EFB Untuk Pulp, menggunakan rumus $\mathrm{I}=(\mathrm{P} \times \mathrm{H})-(\mathrm{C}+(\mathrm{C} * \mathrm{z})) \quad \ldots \ldots \ldots \ldots . .2$

dimana:

I : Pendapatan $(\mathrm{Rp})$

$\mathrm{H}$ : Harga jual pulp per satuan volume (Rp/ton)

C : Biaya produksi pulp dari kayu $(\mathrm{Rp})$

$\mathrm{Z}$ : Faktor pengaman produksi pulp untuk 
bahan EFB (ditentukan sebesar 40\% dari nilai C)

Menurut Silalahi (2007) bahwa biaya produksi (C) yang dikeluarkan oleh PT. RAPP dalam membuat pulp kraft sebesar $133 \mathrm{USD} / \mathrm{ton}$ harga jual $550 \mathrm{USD} /$ ton. Dalam penelitian ini, harga jual pulp kraft dari biomassa EFB adalah sebesar $200 \mathrm{USD} /$ ton.

Untuk menduga nilai tambah, dapat menggunakan persamaan sebagai berikut:

$c v=\left[\frac{\left(H-C_{l}\right)}{\text { rendemen }}\right]-H_{1} \ldots \ldots \ldots \ldots \ldots \ldots \ldots \ldots . . . \ldots \ldots$

Dimana, cv : nilai tambah(USD/ton)

$\mathrm{H}$ : harga per satuan unit produksi

$\mathrm{C}_{1}$ : biaya produksi tanpa bahan baku (USD/ton) dalam hal ini adalah $133 \mathrm{USD} /$ ton

$\mathrm{H}_{1}$ : harga bahan baku(USD/ton)

\section{HASIL DAN PEMBAHASAN}

\section{A. Hasil}

Berdasarkan rata-rata ijin lahan untuk perkebunan kelapa sawit yang diterbitkan per tahun mencapai 269,36 Ha (Gambar 1), tahun 1995 dan 1997 dicadangkan lahan terbesar untuk pembangunan perkebunan kelapa sawit mencapai 900 ribu ha, dengan potensi biomassa EFB dari luas lahan tersebut mencapai $17,1 \mathrm{Mg} / \mathrm{ha}$. Potensi biomassa EFB mencapai 77,6 juta ton di tahun 2025. Angka ini menunjukkan tren yang terus meningkat. Peningkatan ini linier dengan potensi produksi pulp sebagaimana ditunjukkan dengan Gambar 3.

Berdasarkan Gambar 3, pertumbuhan biomassa EFB kecenderungan potensi produksi pulp berbentuk linier. Apabila dimulai pada tahun 2013 biomassa EFB diolah untuk pulp dengan rendemen 40\% (Tanaka et al., 2004), maka produksi pulp selama periode 2013 mencapai 10,3 juta ton dan terus meningkat menjadi 19,78 juta ton di tahun 2025.

Potensi pulp yang dihasilkan akan memberikan tambahan pendapatan ekonomi. Pendugaan nilai tambah ekonomi menggunakan pendekatan produksi pulp dari kayu. Namun, tentunya nilai investasi yang ditanamkan akan lebih besar dibandingkan dengan kayu. Hal ini karena dari sisi pengerjaannya yang lebih kompleks dibandingkan pengelolaan kayu untuk pulp. Untuk itu, faktor pengaman $40 \%$ digunakan untuk produksi pulp dari biomasa EFB diperlukan tambahan $40 \%$ dari nilai investasi produksi pulp dari kayu. Rata-rata pendapatan per hektar dari penjualan biomasa EFB untuk pulp dengan harga jual $200 \mathrm{USD} /$ ton adalah sebesar $28 \mathrm{USD} / \mathrm{Ha}$ di tahun 2013 dan meningkat menjadi 42,57 USD/ Ha di tahun 2025.

Peningkatan nilai disebabkan oleh meningkatnya pendapatan pulp dari produktivitas perkebunan sawit. Bila pada tahun 2013, pengelolaan limbah EFB efektif dijalankan, kelapa sawit yang di tanam pada tahun 2008 sampai dengan tahun 2010 mulai produksi tandan buah untuk minyak sawit dan dapat dimanfaatkan limbah EFB sebagai bahan pulp ditambah akumulasi

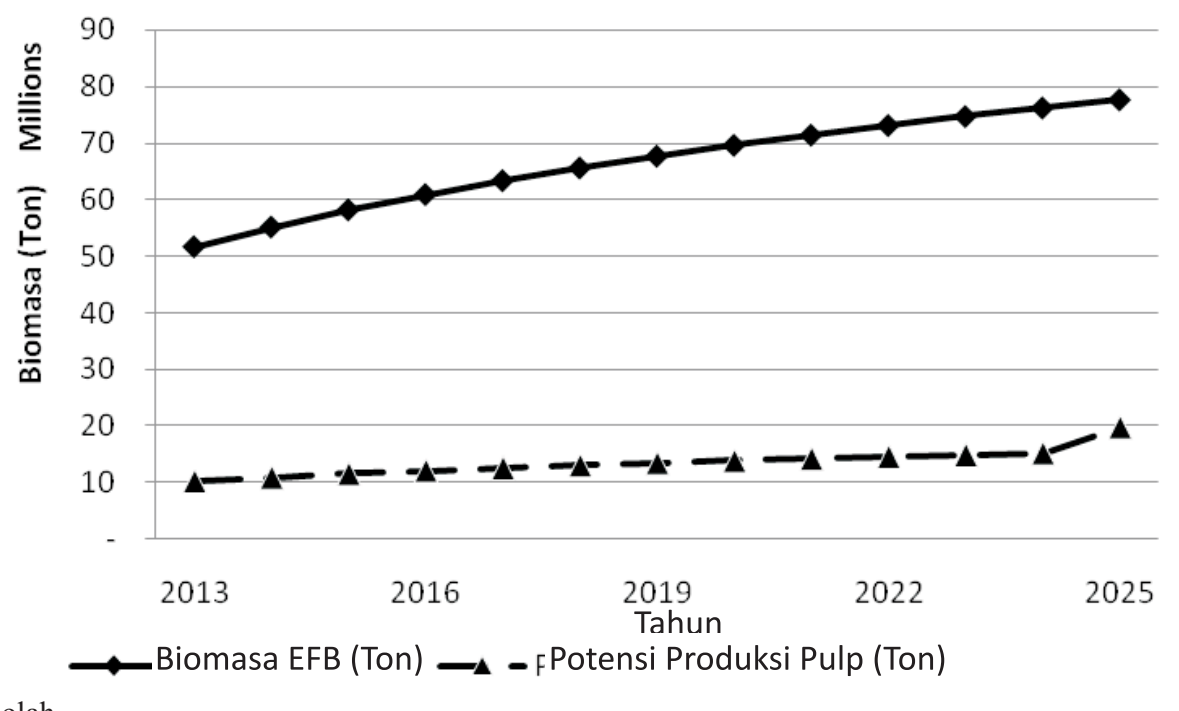

Sumber: Data Diolah

Gambar(Figure) 3. Pertumbuhan biomassa EFB (ton) dan potensi produksi pulp (ton) (Growth of EFB biomass and pulp production) 
kebun sawit yang telah dibangun sebelumnya (Gambar 4).

Namun, kecenderungan peningkatan nilai tidak linier. Hal ini disebabkan oleh pada umur 25-30 tahun dilakukan regenerasi kebun yang tentunya akan menurunkan produktivitas per satuan luas lahan. Namun regenerasi akan mengakibatkan peningkatan nilai sepanjang tidak dilakukan serentak pada seluruh kebun, melainkan dilakukan berdasarkan umur kebun.

Gambar 4 di bawah menunjukkan bahwa pendapatan penjualan hasil olahan EFB untuk pulp meningkat dan akan turun ketika produktivitas buah kelapa sawit pun menurun. Bila di tahun 2013 terdapat kebijakan untuk memanfaatkan EFB sebagai bahan baku pulp, maka kemungkinan terdapat tambahan nilai ekonomi sebesar 142 juta USD dan terus meningkat sampai dengan 214 juta USD di tahun 2024. Atau dengan kata lain, rata-rata pendapatan per hektar dari pemanfaatan biomassa EFB untuk pulp adalah sebanyak $28 \mathrm{USD} /$ ha dan meningkat menjadi 42,5 USD/ha.

Peningkatan pendapatan berdampak pada nilai tambah yang diperoleh bila limbah kelapa sawit dalam bentuk biomassa tandan buah kosong dimanfaatkan untuk pulp. Hasil analisis data menunjukkan bahwa pemanfaatan biomassa tandan buah kosong akan meningkatkan nilai tambah sebesar 33,6 USD/ton. Dengan demikian bahwa pemanfaatan satu ton biomassa tandan buah kosong akan memberikan tambahan pendapatan sebesar 33,6 USD.

\section{B. Pembahasan}

Berkembangnya luasan perkebunan kelapa sawit di Indonesia menyebabkan pembangunan kebun kelapa sawit dianggap sebagai salah satu faktor pendorong rusaknya hutan alam (FWI/ GFW, 2001). Hal ini disebabkan oleh konversi areal berhutan untuk kebun kelapa sawit. Pembangunan kelapa sawit di kawasan hutan dibolehkan bila telah mendapatkan ijin pelepasan kawasan dan atau ijin tukar menukar kawasan.

Yulianti (2009) dan Syahrinudin (2005) menyebutkan bahwa terdapat hubungan yang positif antara biomassa kebun sawit dengan umur. Pada umur 1 tahun, biomassa kebun sawit mencapai 1,28 ton/ha dan terus meningkat menjadi 29,87 ton/ha (Yulianti 2009). Syahrinudin (2005) menyebutkan bahwa pada umur 3 tahun, biomassa sawit mencapai $40,9 \mathrm{Mg} /$ ton dan meningkat menjadi 204,3 Mg/ton.

Namun hubungan ini tidak bersifat linier. Hal ini disebabkan oleh pertumbuhan biomassa sangat dipengaruhi oleh produktivitas fotosintesis yang terjadi. Menurut Sharma (2009) dan Hensson 1991 bahwa kapasitas fotosintesis kelapa sawit menurun mengikuti umur. Artinya bila pada umur tua, laju fotosintesis akan semakin menurun sehingga produksi biomassa pun akan menurun.

Dengan demikian, pola pertumbuhan biomassa kelapa sawit membentuk eksponensial yang pada umur muda pertambahan biomassa akan cen-derung meningkat. Pada umur tua pertumbuhan melambat dan cenderung stagnan.

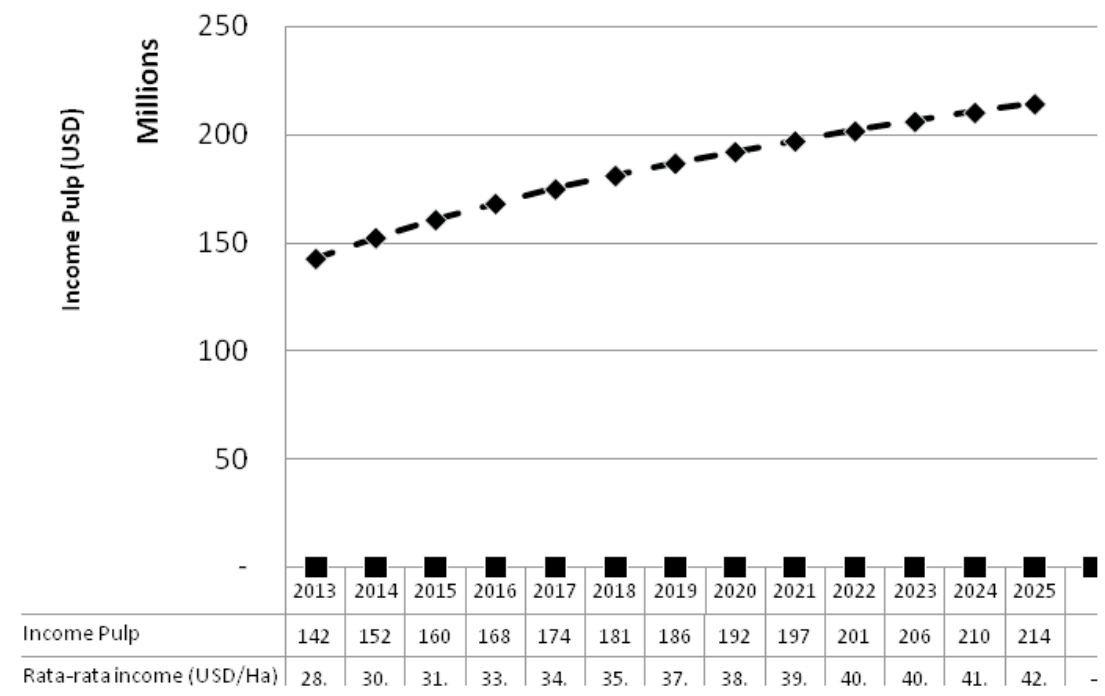

Sumber: Data Diolah

Gambar (Figure) 4. Pendapatan pulp dari pemanfaatan EFB sebagai bahan baku pulp (Pulp income from utilization of biomass EFB as material of pulp) 
Menurut Elbersen et al. (2005) dalam Abdullah et al. (2011) bahwa komposisi limbah EFB terdiri atas 58\% air, 0,80\% Nitrogen, $0,06 \%$ Fospor, 0,24\% Kalium dan 0,18\% Magnesium. EFB dapat menghasilkan kertas yang baik dengan tingkat keputihan (brightness) mencapai 75 - 80\% dapat diolah dengan teknik kimia pencucian klorin (a cloring-free process) (Tanaka et al., 2004).

Hasil simulasi menunjukkan bahwa terdapat peluang peningkatan pendapatan bila limbah kebun kelapa sawit berupa tandan buah kosong dapat diolah menjadi pulp. Rata-rata pertambahan nilai ekonomi per hektar mencapai 113,49 USD/Ha atau bila kerapatan tegakan adalah 130 batang maka nilai pertambahan nilai dari setiap pohon yang dapat memberikan nilai tambah terkait pemanfaatan biomasa untuk pulp adalah sebesar 0,87 USD/batang. Selain mampu meningkatkan pendapatan, pemanfaatan EFB berdampak pada terciptanya diversifikasi produk kelapa sawit di industri kelapa sawit sehingga dapat meningkatkan serapan tenaga kerja.

Tren pendapatan dari hasil pengelolaan pulp berbentuk osilasi. Hal ini artinya pendapatan berfluktuasi dan tidak dapat dirata-ratakan. Pendapatan pulp sangat bergantung pada biomassa EFB yang dipanen dan lahan perkebunan yang telah masuk umur produktif. Ketika saat regenerasi maka produksi EFB akan menurun dan berakibat pada menurunnya pendapatan dari pengelolaan EFB untuk pulp.

Beberapa hal yang berpengaruh terhadap pemanfaatan limbah EFB adalah tersebarnya lokasi perkebunan kelapa sawit (Sumatera dan Kalimantan) sehingga akan membutuhkan biaya tambahan untuk kegiatan pengumpulan limbah EFB. Selain itu, yang berpengaruh pada kelimpahan bahan baku adalah penanaman yang tidak serempak.

Pemanfaatan limbah EFB untuk pulp akan mampu memenuhi kebutuhan kertas dan pulp nasional. Produksi pulp Indonesia sampai tahun 2011 mampu mencapai 10 juta ton atau $83 \%$ dari kebutuhan nasional sebesar 12 juta ton (Misbahul 2012). Dengan memanfaatkan limbah EFB mampu menyediakan pulp sebesar 81,95 juta ton (asumsi rendemen $40 \%$ ). Pertambahan nilai ekonomi dari pemanfaatan biomassa limbah EFB sebesar 33,6 USD/ton menjadi tantangan tersendiri dalam meningkatkan nilai kawasan hutan yang dikelola untuk produksi kayu. Meningkatkan luas ijin kelapa sawit tentunya akan meningkatkan nilai ekonomi lahan yang lebih menarik, meski pembangunan kelapa sawit cenderung mengonversi lahan bertutupan hutan menjadi kebun.
Selama ini perkebunan kelapa sawit menggunakan IPK (Ijin Pengambilan Kayu) perkebunan sebagai modal usahanya. NPV proyek perkebunan kelapa sawit meningkat menjadi USD 93,62 juta jika dibandingkan dengan perkebunan kelapa sawit tanpa mengelola IPK yang hanya memperoleh NPV sebesar USD 72,62 juta (dan nilai IRR sebesar 26,35\%) pada lahan seluas 10 ribu hektar dan tingkat suku bunga diskonto $10 \%$.

Produksi CPO sebagai satu-satunya produk perkebunan kelapa sawit, investor dapat memperoleh keuntungan mencapai USD 72,62 juta. Namun hal ini akan bertambah jika terdapat kebijakan pemanfaatan limbah EFB, investor dapat memperoleh keuntungan mencapai USD 912,96 juta. Angka ini jauh lebih besar ketika pemberian ijin perkebunan kelapa sawit baru yang mengkonversi kawasan hutan melalui ijin IPK.

Dengan demikian, diversifikasi produk CPO dan pemanfaatan limbah kelapa sawit dapat mengurangi ancaman konversi kawasan hutan dan mengalihkan perhatian investor kelapa sawit dari peningkatan luas lahan usaha menjadi peningkatan volume diversifikasi produk dan pemanfaatan limbah serta merangsang jenis investasi lainnya.

\section{KESIMPULAN}

\section{A. Kesimpulan}

1. Ijin pembangunan perkebunan kelapa sawit dari tahun 1995 - 2010 memproduksikan biomassa limbah EFB mencapai 10,27 ton/ha 15,42 ton/ha.

2. Potensi biomassa limbah EFB dimanfaatkan untuk bahan baku pulp akan memberikan tambahan pendapatan tertinggi mencapai 142 juta USD sampai dengan 214 juta USD atau ratarata pendapatan per hektar mencapai $28 \mathrm{USD} /$ Ha sampai dengan 42,5 USD/Ha.

3. Nilai tambah yang diperoleh bila memanfaatkan biomassa tandan buah kosong mencapai 33,6 USD/ton.

\section{DAFTAR PUSTAKA}

Abdullah, M.A., M.S. Nazir dan B.A. Wahjoedi. 2011. Development of Value-Added Biomaterials from Oil Palm Agro-Waste. 2nd International Conference on Biotechnology and Food Science IPCBEE vol.7 (2011). 
Boons, F. and A. Mendoza. 2010. Constructing Sustainable Palm Oil: How Actors Define Ssustainability. Journal of Clean Production 18 (2010): 1686-1695.

ABPS. "Luas tanaman Perkebunan Menurut Jenis Tanaman 1995-2000". [Online] 11 Januari 2012. http://www.bps.go.id/ tab sub/ view.php? tabel $=1 \&$ daftar $=1 \& \mathrm{id}$ subyek $=$ $54 \&$ notab $=1$.

Chan, J.Y., M.F. Chong and C.L. Law. 2010. Biological Treatment of Anaerobically Digested Palm Oil Mill Effluent (POME) Using a Lab-Scale Sequencing Batch Reactor (SBR). Journal of Environmental Management 91 (2010): 1738-1746.

FWI/GFW. 2001. Keadaan Hutan Indonesia. Bogor, Indonesia: Forest Watch Indonesia dan Washington D.C.: Global Forest Watch.

Kementerian Pertanian. "Peranan Perkebunan Tetap Penting. Sambutan Menteri Pertanian Dalam Memperingati Hari Perkebunan”. [Online] 2 April 2012. http://ditjenbun.deptan.go.id/ index.php/ component/content/article/36news/239-menteri-pertanian-perananperkebunan-tetap-penting.html.

Manurung, E.G.T. 2001. Analisis Valuasi Ekonomi Investasi Perkebunan Kelapa Sawit di Indonesia. Laporan Teknis. Environmental Policy and Institutional Strengthening IQC. Jakarta.

Media Indonesia. "Gapki Proyeksikan Produksi Minyak Sawit Tembus 25 Juta Ton”. [Online] 11 Januari 2012 http://www. bisnis.com/ articles/gapki-proyeksikan-produksi-minyaksawit-tembus-25-juta-ton.

Misbahul. 2012. "Konsumsi Pulp dan Kertas Bisa Tumbuh 4\%". [Online] 26 Januari 2012. http://economy.okezone.com/read/ 2012/ 01/12/320/555991/konsumsi-kertas-dan-pulpbisa-tumbuh-4.
Mystri. 2012. Produksi CPO Indonesia 2012 Naik 1-1,4 Juta Ton. [Online] 24 Februari 2012. http://www.investor.co.id/ agribusiness/ produksi-cpo-indonesia-2012-naik-1-14-jutaton $/ 25563$

Sharma, B. 2009. Modelling Carbon Stock in Oil Palm Using Sistem's Approach. Thesis: International Institute for Geo-Information Science And Earth Observation Enschede, The Netherlands.

Silalahi, Y.M.P. 2007. Analisis Biaya produksi Pulp: Studi kasus di PT. Riau Andalan Pulp dan Paper (PT. RAPP) Pangkalan Kerinci - Riau. Skripsi: Departemen Hasil Hutan IPB. Bogor

Syahrinudin. 2005. The Potential of Oil Palm and Forest Plantation for Carbon Sequestration on Degraded Land in Indonesia. Ecology and Development Series No.28. Cuvillier Verlag Gottingen.

Tanaka, R., Mori Y. and Kosugi A. 2006. Utilization Of Oil Palm Empty Fruit Bunches As 'Solid Materials'. Forestry and Forest Products Research Institute, Japan and Japan International Research Center for Agricultural Sciences.

Tanaka,R., Wan Rosli W.D., K. Magara, T. Ikeda dan S. Hosoya. 2004. Chlorine-Free Bleaching of Kraft Pulp from Oil Palm Empty Fruit Bunches. JARQ 38 (4), 275 - 279 (2004).

Wan Asma, I., S. Mahanim, H. Zulkafli, S. Othman and Y. Mori. 2010. Malaysian Oil Palm Biomass. Bahan Presentasi pada Regional Workshop on UNEP/DTIE/ IETC kolaborasi dengan GEC. 2-5 Maret 2010. Osaka. Jepang.

Yulianti, N. 2009. Cadangan Karbon Lahan Gambut Dari Agroekosistem Kelapa Sawit PTPN IV Ajamu, Kabupaten Labuhan Batu, Sumatera Utara. [Tesis] Sekolah Pascasarjana Institut Pertanian Bogor. 